\title{
自己覚醒法による短時間仮眠後の睡眠慣性抑制効果
}

\author{
広島大学 \\ 甲斐田幸佐・入戸野 宏 \\ 林光緒・堀忠雄
}

\section{Preventive effects of self-awakening on sleep inertia a short nap}

Kosuke Kaida, Hiroshi Nittono, Mitsuo Hayashi, and Tadao Hori

Department of Behavioral Sciences, Faculty of Integrated Arts and Sciences, Hiroshima University, 1-7-1 Kagamiyama, Higashi-Hiroshima, 739-8521, Japan

A short nap is effective to prevent the afternoon arousal reduction (i.e., post lunch dip). However, sleep inertia remains just after awakening from nap. This study examined whether the self-awakening prevent sleep inertia after short nap. 10 healthy graduated students participated in the study. They took a nap from 14:00 for around $15 \mathrm{~min}$ in the self-awakening condition or for $20 \mathrm{~min}$ in the forced-awakening condition from lights off. A 5-min session consisting of auditory oddball task (4min) and Visual analog scale (VAS: 1 $1 \mathrm{~min}$ ) was carried out continuously twice (10 min) before and six times (30min) after the nap. P300 amplitude of the event related potential was used to evaluate arousal levels. The VAS was used to evaluate feeling of sleepiness. P300 amplitudes during postnap sessions reduced significantly in the forced-awakening condition, while such reduction was not observed in the self-awakening condition. These results indicated that the arousal level after the nap was lower in the forcedawakening than the self-awakening condition. For the VAS scores, a feeling of sleepiness was improved after the nap. Especially, the improvement was greater in the self-awakening than forced-awakening condition. These results suggest that self-awakening was effective to reduce a post nap sleep inertia.

Key words: nap, sleep inertia, self-awakening, P300 amplitude

【要＼cjkstart約】 午後の眠気（post lunch dip）を抑制するために短時間仮眠が有効であるが，仮眠後には睡 眠慣性が残る．本研究では，短時間仮眠後の睡眠慣性を低減させることを意困して，自己覚醒の効果を 検討した．実験参加者は，大学生・大学院生10名であった。参加者は14:00から, 強制覚醒条件では20 $\min$, 自己覚醒条件では約 $15 \mathrm{~min}(10-20 \mathrm{~min})$ の仮眠をとった，仮眠前に 2 セッション $(10 \mathrm{~min})$, 仮眠後 に 6 セッション $(30 \mathrm{~min})$ の課題を行った。課題は，客観的覚醒水準の指標であるP $300 を$ 測定するため の聴覚オドボール課題と主観的眠気および気分を測定するためのVisual analog scale（VAS）を用いた. 分析の結果, 仮眠後のP300振幅は, 強制覚醒条件で有意に減少したが, 自己覚醒条件では変化しなかっ た.また，仮眠後の主観的眠気および気分は，強制覚醒条件より自己覚醒条件で有意に改善した．以上 の結果は，自己覚醒が仮眠後の睡眠慣性を抑制するために効果的であることを示唆している.

2001.1.29 受稿, 2001.3.13 受理

本研究は, 文部科学省の平成12年度科学技術振興調整費による「日常生活における快適な睡眠の確保に関する総合 研究」の一環として行われた. 


\section{序論}

14:00から 16:00に生じる強い眠気（post-lunch dip）が, 覚醒水準や作業効率を低下させること は，広く知られている (Broughton, 1989, 1998). また，日中の交通事故は，14:00から16:00に頻発 しており，この時間帯の眠気対策が必要とされて いる (Lavie, Wollman, \& Pollack, 1986; Mitler, Carskadon, Czeisler, Dement, Dinges, \& Graeber, 1988; Pack, Pack, Rodgman, Cucchiara, Dinges, \& Schwab, 1995).

午後の眠気対策として短時間仮眠が有効であ る. 先行研究で用いられている仮眠時間は $15 \mathrm{~min}$ （前田・有富 - 白川, 1994; Takahashi \& Arito, 2000）または20min（Hayashi, Ito, \& Hori, 1999a; Hayashi, Watanabe, \& Hori, 1999b) であり, どち らに扮いても眠気抑制効果が認められている。仮 眠時間を短時間 (30min未満) にする目的は以下 の 2 つである，ひとつは，仮眠中に徐波睡眠へ到 達することを防ぎ，日中の仮眠が，その後の夜間 主睡眠に与える入眠潜時の延長などの悪影響 (Karacan, William, Finley, \& Hursch, 1970) を防ぐ ことである.もうひとつは，徐波睡眠から覚醒す ることによって覚醒直後に残る強い眠気（睡眠慣 性）を最小限に抑えることである（Stampi, Mullington, Rivers, Campos, \& Broughton, 1990; Hayashi et al., 1999a, b). 睡眠慣性は作業効率を 低下させ生活に悪影響を及ぼすため（Dinges， 1989，1992），仮眠をとる際には，これらの制御 が重要であると考えられている（玉木・城田・林 ·堀, 1999).

本研究では，仮眠直後の睡眠慣性を抑制するた めに自己覚醒 (self-awakening) を用いる。自己 覚醒とは, ヒトがあらかじめ意図した時刻，また は一定の経過時間後に自発的に覚醒することをい う (Moorcroft, Kayser, \& Griggs, 1997)。これに 対して, 目覚まし時計などを使って，ある時刻ま たは一定の経過時間後に強制的に覚醒することを 本研究では強制覚醒と呼ぶ。夜間睡眠において, 日常的に自己覚醒を行っているヒトは全体の $23 \%$ であり, 目覚し時計のベルが鳴る前に必ず目覚め る場合を合わせると $52 \% に$ 達することが報告され ている (Moorcroft et al., 1997)。このことから,
自己覚醒は日常的によく経験される現象であると 考えられる。

自己覚醒を習慣的に行っているヒトでは, 目覚 める以前から覚醒の準備がおこなわれるため (Born, Hansen, Marshall, Malle, \& Fehm, 1999), 気持ちよく目覚めることができると考えられてい る。逆に，自己覚醒を意罒することが睡眠を浅く し，主観的な睡眠の質を低下させるという報告も ある（Bell，1980; Carskadon, Herman, \& Davis, 1990; Hawkins, 1989; Hawkins \& Shaw, 1990). 一 方で，入眠から90minでは，自己覚醒を意図した 場合と意図しない場合で, 睡眠ポリグラフで測定 した睡眠内容に，差が認められないと報告されて いる（渡辺，1969）.自己覚醒をすることにより， 睡眠からの円滑な覚醒が可能となれば, 自己覚醒 を用いて目覚めた際の睡眠慣性は強制覚醒よりも 低く抑えられると考えられる。

これまで，睡眠慣性の測定にはVisual analog scale (VAS) や (Hayashi et al., 1999a, b),事象関 連電位 (event related potential: ERP) が用いられ てきた (Takahashi \& Arito, 1998, 2000). VAS は, 主観的な眠気や気分を評定する方法で， $100 \mathrm{~mm}$ の直線の両端に, 例えば「眠い」「目覚めている」 などの言葉が配置されている．参加者は, 自分の 状態に最もあてはまる部分に記しをつけ，現在の 状態を表現する，VASの測定については，妥当性 と信頼性が確かめられている（Monk, 1989)。ER Pでは, 特にP300振幅が覚醒水準の指標として用 いられている (Broughton, Aguirre, \& Dunham, 1988; Walsleben, Squires, \& Rothenberger, 1989; Ruijter, Ruiter, \& Snel, 2000). Broughton et al. （1988）の報告によると，ナルコレプシー患者で は, 健常者に比べて日中の眠気が強く, 睡眠潜時 反復テスト（multiple sleep latency test: MSLT）を 実施した際の入眠潜時は短く, P300振幅も低い. また, Ruijter et al. (2000) は, カフェインを摂取 することにより，作業効率の向上とともにP 300 振幅は増大することを報告している。これらの知 見から，P300振幅值が覚醒水準の指標として考 えられており，振幅が大きいほど覚醒水準が高い とみなされている。従って, 本研究では, P300 振幅を覚醒水準の生理的な指標として用いた。 
本研究の目的は, 自己覚醒の持つ睡眠慣性抑制 効果を明らかにすることとし, 以下の仮説を検討 した。

1. 自己覚醒により覚醒した方が，強制覚醒により 覚醒した場合よりも仮眠後のパフォーマンスが 高い.

2.自己覚醒により覚醒した方が，強制覚醒により 覚醒した場合よりも仮眠後のP300振幅が大き w.

3. 自己覚醒により覚醒した方が, 強制覚醒により 覚醒した場合よりも仮眠後の主観的眠気は低 い.

\section{方 法}

\section{参加者}

健常大学生・大学院生14名（男性 6 名, 女性 8 名：平均年齢 $21.3 \pm 1.34$ 歳）を対象とした。参加 者は, 夜間睡眠において自己覚醒経験があり, 仮 眠習慣を持っていなかった，参加者は，実験開始 3 日前から睡眠日誌に記入した。この睡眠日誌を 用いて, 実験日前の睡眠時間や就寝・起床時刻が 普段よりも特にずれていないことを確認した。参 加者には，実験前日から実験が終了するまで，ア ルコールは摂取しないよう教示した。また，実験 当日は, カフェイン，ニコチン，その他の覚醒調 整作用のある嗜好品や飲食物は捸取しないよう要 請した。参加者には, 研究目的, 実験内容を十分 に説明し，実験参加への同意を得た。

\section{課題}

P300振幅值の測定には聴覚オドボール課題を 用いた。刺激は， $1200 \mathrm{~Hz}(20 \%$, Target $)$ と 1000 $\mathrm{Hz}$ (80\%, Non-Target) のピップ音（持続時間100 $\mathrm{ms}$, rise/fall 10ms, 60dB) をヘッドホンからラン

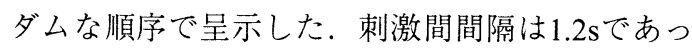
た. 1 セッションにつき200回の刺激を呈示し， 低頻度刺激を標的刺激とした，参加者には，標的 刺激検出後できるだけ早く右手第二指でボタン押 しをするように求めた。なお，主観的眠気の測定 には，100mmスケールのVAS（Monk, 1989）を 使用した。

\section{手続き}

参加者は実験順応条件，自己覚醒による仮眠 （自己覚醒条件：self-awakening）と強制覚醒によ る仮眠 (強制覚醒条件: forced-awakening) を 1 日 づつ, 計 3 日間実験に参加した。各条件には 3 日 以上の間隔をあけた。自己覚醒条件と強制覚醒条 件の実施順序は, 参加者間でカウンターバランス をとった．実験のタイムスケジュールをFig. 1に 示した，参加者は，脳波，眼電位，願筋電位を記 録するための電極を装着したあと，13:45から 2 セッション $(10 \mathrm{~min})$ の課題を行った。課題 1 セッションは, 聴覚オドボール課題 $4 \min$ と, そ

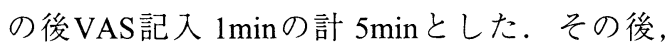
ベッドに移動し, 安静状態を保った（計 $5 \mathrm{~min}$ ). 仮眠直前にVAS記入を行い，14:00から仮眠を開 始した，仮眠終了後は，すぐにVAS記入を行い， 椅子に移動したあと同様の課題を 6 セッション (30min) 行った。自己覚醒条件では，「消灯から

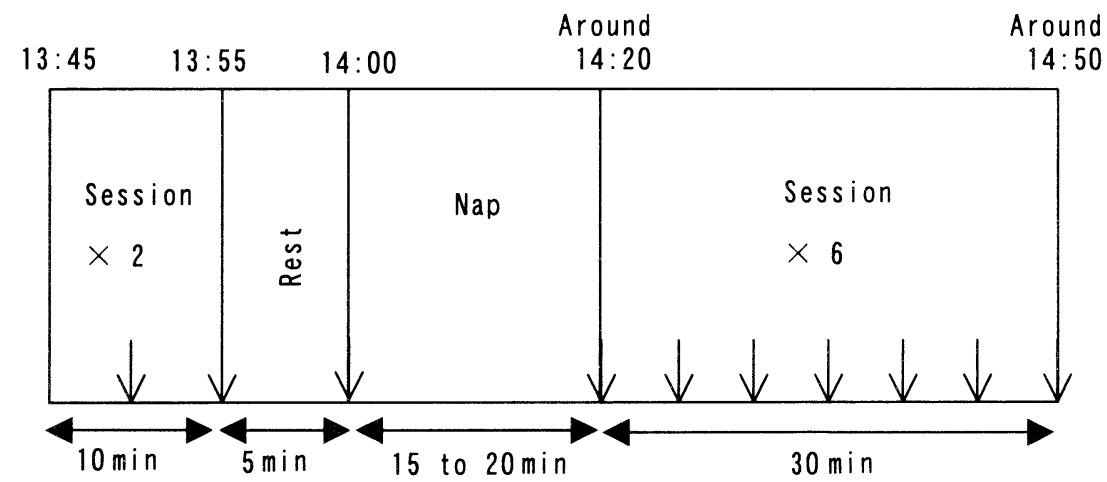

Fig. 1 Time schedule of the experiment. Each session is consisted of VAS scoring and Oddball task which lasted 5 minutes. The vertical arrows in the figure indicate the timing of VAS ratings. 
15分経過したと思った時点で, 手もとのボタンを 押して下さい.」と教示した。自己覚醒成功基準 は, 覚醒予定時刻から士5min以内とし，仮眠時

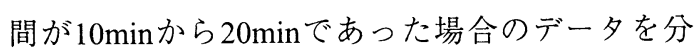
析に用いた。強制覚醒条件では，「こちらから声 をかけるまで寝て下さい」と教示し，自己覚醒条 件における最大許容仮眠時間に揃えて, 消灯から $20 \mathrm{~min}$ 経過した時点で実験者がインターコムで声 をかけて覚醒させた。

\section{記録}

脳波は国際10-20法に基づいて頭皮上の 5 部位 ( $\mathrm{Fz}, \mathrm{Cz}, \mathrm{Pz}, \mathrm{C} 3, \mathrm{O} 1)$ 加両耳㭼連結を基準部位 として導出した。このうち 3 部位 $(\mathrm{Fz}, \mathrm{Cz}, \mathrm{Pz}$; 時 定数: $3.2 \mathrm{~s})$ を ERP測定用とし, 他の 2 部位（C3, O1; 時定数: $0.3 \mathrm{~s}$ ) を用いて睡眠段階を判定した. 垂直眼球運動は, 眼窩下縁と 眼窩上縁から, 水 平眼球運動は, 両眼窩外側縁からそれぞれ双極導 出した (時定数: $3.2 \mathrm{~s}$ ). また, 頣筋電位 (時定数: 0.03s）を双極導出し，ストレインゲージ法を用 いて胸部及び腹部の呼吸運動を記録した. 頭皮上 電極の接触抵抗值はすべて $5 \mathrm{k} \Omega$ 以下とした。記 録は紙記録（NEC三栄製1A97型ポリグラフ）と デジタル記録（Dell製Optiplex GX1,キッセイコム テック製Bimutus II）を同時に行い，デジタル記 録時のサンプリング周波数は $500 \mathrm{~Hz}$ とした.

ERPの測定 刺激呈示前 $100 \mathrm{~ms}$ をベースラインと して, 刺激呈示前 $100 \mathrm{~ms}$ から刺激呈示後 $500 \mathrm{~ms}$ ま での脳波を参加者, 条件, 刺激タイプごとに加算 平均した。 その際, 誤反応試行および, 脳波と眼 電位のいずれかのチャンネルで分析区間内に \pm 80 $\mu \mathrm{V}$ 以上の変動を含む試行は除外した。 その後, 総加算平均波形から, P300頂点を刺激後250-500 $\mathrm{ms}$ の範囲内の最大陽性ポイントとして同定した。 本研究で得られたP300はPz部位で振幅が最大と なったため, 本報告での分析はPz部位に限った. 総加算平均から得られた課題各セッションのP 300 潜時から $\pm 20 \mathrm{~ms}$ を平均振幅算出区間とし, 各 参加者でセッションごとに区間平均電位を算出し た。

睡眠ポリグラフ指標 Rechtschaffen \& Kales （1968）の基準に従って，20s毎に睡眠段階を判定 し，睡眠変数を算出した。また，睡眠中の $3 \mathrm{~s}$ 以
上の微小覚醒 (micro arousal; 杉田・川上・渡辺 ·谷口・寺島・漆葉, 1998）の数を, ASDA (American Sleep Disorders Association and Sleep Research Society, 1992）の基準にしたがって算出し た。

統計分析 統計学的分析は, Windows版SAS ver 6.12を使用して, 繰り返しモデルによる 2 要因分 散分析（条件メセッション）を行った. 自由度 は, Huynh-Feldtのをを用いて調整した。下位検 定には，Tukey HSD検定および対応のある $\mathrm{t}$ 検定 を用いた。

\section{結 果}

自己覚醒できた参加者（自己覚醒成功者）は， 14名中 10 名（71\%）であった。自己覚醒できな かった参加者は， 2 名であり，残る2名は入眠す ることができなかった，従って，自己覚醒ができ た参加者10名（男性 4 名, 女性 6 名）のデー夕の みを分析に用いた。

睡眠変数 自己覚醒成功者の平均睡眠内容を Table 1 に示した。自己覚醒条件における覚醒時 刻は予定覚醒時刻よりも $1.1 \pm 0.99 \mathrm{~min}$ 早かった。 全睡眠時間は, 強制覚醒条件 $(18.3 \pm 0.61 \mathrm{~min})$ より自己覚醒条件 $(13.8 \pm 1.18 \mathrm{~min})$ で有意に短 かった $(t(9)=3.49, p<.01)$. その他の変数におい ては，両条件間で有意差が認められなかった。ま た，覚醒直前の睡眠段階は，自己覚醒条件では， Stage 1 が 2 名, Stage 2 が 7 名, Stage REMが 1 名であった。強制覚醒条件では, Stage 1 が 2 名, Stage 2 が 8 名で, 条件間に睡眠段階分布（比） の差は認められなかった。

課題成績 課題正反応率は, 画条件のすべての セッションにおいて $99.9 \%$ 以上であった。一方, 課題正反応時間において, 条件の主効果および交 互作用は認められなかった。

P300頂点振幅 - 頂点潜時 $\mathrm{P} 300$ 振幅の時系列変 化を, Fig. 2 に示した。 セッションの主効果が認 められ $(F(7,63)=3.77, p<.05, \varepsilon=.42)$, 強制覚 醒条件において, 仮眠前 $5 \mathrm{~min} よ り も$ 仮眠後 $15 \mathrm{~min}$ のP300振幅值が有意に低下していた $(p<.05)$.ま た，条件とセッションの間に交互作用が認められ た $(F(7,63)=2.20, p<.05, \varepsilon=.91)$. 下位検定の 
甲斐田 他：自己覚醒による短時間仮眠の効果

Table 1 Means of sleep variables in the afternoon nap. The parentheses are SEs.

\begin{tabular}{rcccc}
\hline & Self-awakeing & Foced-awakening & $t$ & $p$ \\
\hline Total sleep time (min) & $13.8(1.18)$ & $18.3(0.61)$ & 3.5 & $<0.01$ \\
Latency to stage 1 (min) & $2.4(0.65)$ & $1.7(0.61)$ & 1.0 & 0.33 \\
Sleep efficiency & $84.7(4.20)$ & $91.7(3.06)$ & 1.6 & 0.15 \\
\%Wake & $4.70(2.3)$ & $7.83(2.6)$ & 1.2 & 0.25 \\
\%Stage 1 & $46.65(6.8)$ & $37.93(6.5)$ & 1.2 & 0.17 \\
\%Stage 2 & $41.38(7.6)$ & $53.37(8.2)$ & 1.4 & 0.19 \\
\%Stage 3 & - & - & - & - \\
\%Stage 4 & - & - & - & - \\
\%Stage REM & $7.27(7.2)$ & - & 1.0 & 0.34 \\
EEG arousals (times) & $4.4(1.51)$ & $6.1(1.36)$ & 1.0 & 0.34 \\
\hline
\end{tabular}

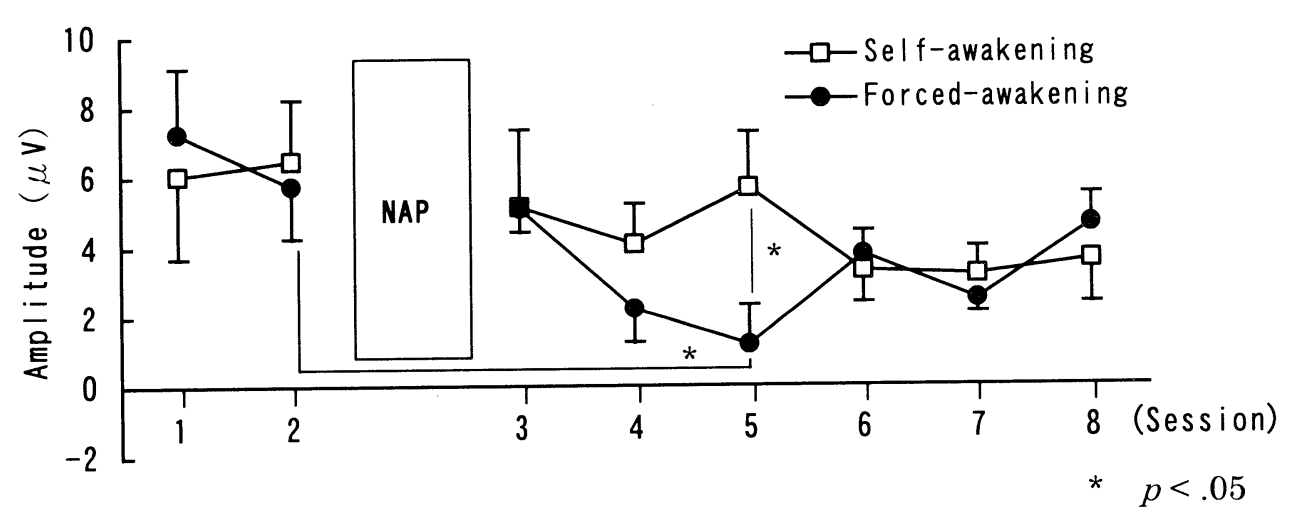

Fig. 2 P300 amplitudes before and after nap. Vertical bars indicate standard errors.

結果, P300振幅は，仮眠後15minで，自己覚醒条 件より強制覚醒条件で有意に低下していた $(t(9)$ $=2.18, p<.05)$ 一方, P300頂点潜時には, 主効果 及び交互作用は認められなかった。

VAS得点 主観的眠気評価の結果をFig. 3に示し た、図の縦軸は、VAS得点が高いほど眠気が強い ことを示している．仮眠後の眠気は，強制覚醒条 件より, 自己覚醒条件で改善しており, 条件間に 主効果が認められた $(F(1,9)=7.53, p<.05)$. 条

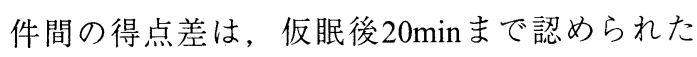
(有意傾向差: $p<.10$ を含む).また，条件とセッ ションの間に交互作用の傾向差が認められた（F $(9,81)=1.79, p<.10, \varepsilon=.79)$.下位検定の結果, 自己覚醒条件においてセッションの単純主効果が 認められ $(F(9,81)=3.13, p<.05, \varepsilon=.39)$, 仮眠直

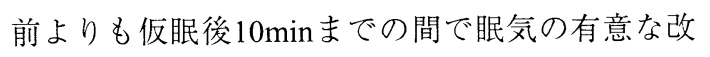

善が認められた（有意傾向差: $p<.10$ を含む).

\section{考察}

本研究の結果, 自己覚醒が短時間仮眠後の睡眠 慣性を抑制することが明らかとなった。また，自 己覚醒時刻は覚醒予定時刻より平均して $1.1 \mathrm{~min}$ 早 く, 仮眠時間は自己覚醒条件では強制覚醒条件と くらべて短くなった. Lumley et al. (1986) は, 60 分以内の短時間仮眠では仮眠時間が長いほど, 仮 眠後の眠気改善効果が大きいことを報告してい る. 本研究では強制覚醒条件の仮眠時間が長かっ た。したがって，仮眠時間たけをを考慮すると，強 制覚醒条件のほうが仮眠後の覚醒水準は高くなる はずである，ところが，自己覚醒条件のほうが仮 眠後の覚醒水準は高く維持されていた。この結果 から, 自己覚醒が仮眠後の覚醒水準の維持に有用 であるといえる。 


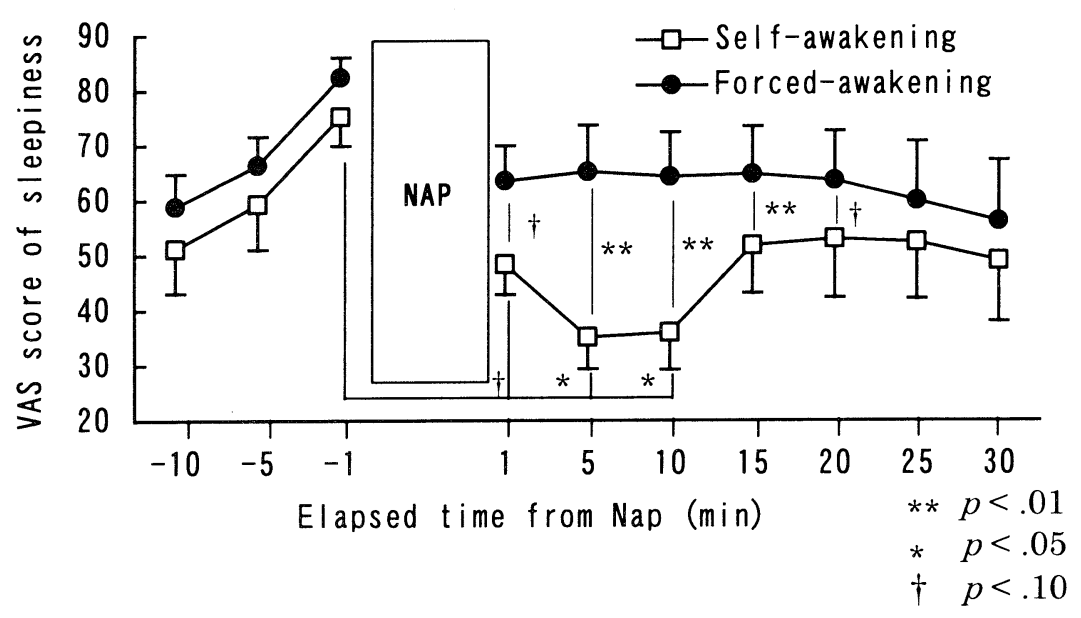

Fig. 3 VAS scores of sleepiness before and after nap. Vertical bars indicate standard errors.

一方, 先行研究で認められている, 仮眠直後の 強い睡眠慣性（Stampi et al., 1990; Hayashi et al., $1999 \mathrm{a}, \mathrm{b})$ は両条件において認められなかった。 この原因として，入眠前にすでに生じている午後 の強い眠気のため, 仮眠後の睡眠慣性が出現して いないようにみえた可能性が考えられる. 本研究 では, 入眠前に約 $5 \mathrm{~min}$ の仰臥開眼安静状態を設 けた。このため, 仮眠開始直前の眠気が上昇し, 仮眠後の睡眠慣性として現われる眠気よりも強く なったと考えられる，このことから，仮眠後の睡 眠慣性を検出するには, 入眠前に眠気を強く喚起 するような状況に参加者を置かないよう留意する 必要性が示唆された。

自己覚醒の成功者は71\%であった。この結果 は, 夜間睡眠において睡眠ポリグラフ記録を行っ た場合の自己覚醒成功率18\% (Zepelin, 1986), 36\% (Lavie et al., 1979), 42\% (Zung \& Wilson, 1970）と比べて, 高い結果となった。今回は, 自 己覚醒の経験者を実験参加者に選定したため, 成 功率を高めることができたと考えられる.今後, 自己覚醒の経験を持たない人を対象にしても同じ 結果になるかどうか検討する必要があるだろう。

起床時の睡眠慣性は, 覚醒直前の睡眠段階が深 いほど強くなることが知られている (Stampi et al., 1990)。このため, 覚醒直前の睡眠段階を統 制して条件間比較を行う必要がある。本研究で は, 睡眠変数の項で述べたように, 条件間に覚醒
直前の睡眠段階に違いが認められなかった。した がって, 覚醒直前の睡眠段階に規定される睡眠慣 性の強さは, 条件間でほとんど変わらないと考え ることができる。

課題正反応時間は, 両条件間で有意差がなく, 仮説 1 を支持しなかった。これは, 反応時間検出 に用いた聴覚オドボール課題の難易度が低すぎ て，反応時間に天井効果が生じた結果であると考 えられる。現に，課題正反応率も $99.9 \%$ で，ほほ 上限值を示している。従来, 論理課題 (Baddeley, 1968), 記憶課題, 減算課題 (Stampi et al., 1990) などの反応時間には仮眠の効果が確かめられてい る (Hayashi et al., 1999a, b; Takahashi \& Arito, 1998, 2000). 今後は, 課題内容や作業の性質によ る睡眠慣性の表出の違いを検討する必要があるだ ろう。

仮眠後のP300振幅值は, 自己覚醒条件よりも 強制覚醒条件で低下していた。この結果は, 仮説 2を支持するものであった。強制覚醒条件におい ては, 仮眠前 $5 \min$ と比べて, 仮眠後 $15 \min て ゙$ 有意 に低下していた。P300振幅值が高いほど，覚醒 水準は高いと考えられる (Broughton et al., 1988; Walsleben et al., 1989; Ruijter et al., 2000) ことか ら, 強制覚醒条件では, 仮眠後に約 $15 \min の$ 覚醒 水準の一時的な低下が認められたといえる。一 方, 自己覚醒条件では, 仮眠後のP 300 振幅低下 は認められなかった。従って, 自己覚醒による覚 
よる覚醒水準の回復・向上は認められなかった が，仮眠直後に覚醒水準が低下することは抑止さ れていると考えてょいであろう。また，Fig. 2を 見ると，全体的な傾向として，両条件において， 時間が経過するにつれてP300振幅値がゆるやか な低下勾配を示している。これは，単調なオド ボール課題を繰り返し行った結果による，慣れ (habituation effect: Ravden \& Polich, 1999）の影響 であると考えられる。

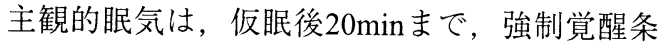
件よりも自己覚醒条件で低減していた。このこと から，仮眠における自己覚醒は，強制覚醒よりも 仮眠後の主観的眠気の改善効果が高く，その効果 は仮眠後20min続いたといえる。したがって，仮 説 3 は支持された。

本来, 睡眠慣性は, 仮眠直後に最も強く現れる と考えられる (Stampi et al., 1990). しかし, 本 研究では，主観的眠気・生理的覚醒水準ともに， 仮眠後 $10 \mathrm{~min} ， 15 \mathrm{~min}$ に比べて仮眠直後に改善し ていた．仮眠直後に実験者がシールドルーム内に 入室した際の音などの影響で，主観的眠気は一時 的に低減した可能性がある。また, 参加者は, 聴 覚オドボール課題の準備のために，覚醒直後に ベッドから椅子に移動する必要があった。この際 の体動で，覚醒水準が一時的に上昇した可能性が ある．仮眠直後の睡眠慣性を検出するために，今 後は課題方法を工夫する必要があるだろう.

仮説 2 および 3 が支持されたことから，自己覚 醒を利用した短時間仮眠は，睡眠慣性が相対的に 弱いときにはすがすがしい覚醒感をもたらし，睡 眠慣性が強いときでもこれと拮抗相殺して, 覚醒 後の心理・生理状態を適正に保つ効果をもつと考 えられる。この効果は，一時的ではあるが睡眠慣 性とは逆に眠気を抑える効果であり，これまでに 報告されていない現象である.

興味深いことに，強制覚醒条件において仮眠前 後のVAS（主観的指標）得点とP300振幅（生理 的指標）は矛盾した結果を示した。強制覚醒条件 において，仮眠後 $15 \mathrm{~min} て ゙ P 300$ 振幅は低下してお り，覚醒水準が低下していた。このことから，仮 眠後 $15 \mathrm{~min}$ 経過すると, 主観的眠気は上昇すると 考えられる。しかし実際には, 主観的眠気の上昇
はみられず，仮眠後で一定水準を維持していた。 したがって，仮眠直後に主観的な眠気が改善して いるようでも，仮眠後 $15 \mathrm{~min}$ は睡眠慣性が完全に 消失したわけではなく，覚醒水準は低下したまま であるといえる。

以上の結果を合わせて考えると，強制覚醒で覚 醒した直後から約 $15 \mathrm{~min}$ までは，覚醒水準が低下 したままであるため，主観的には眠くないと感じ ても，車の運転などの小さな誤反応が重大な事故 につながるような作業（Mitler et al., 1988）は控 えるべきであると考えられる。このような主観的 眠気と客観的覚醒水準のずれは，VASとTwo nap sleep test（TNST）を用いた研究でも確認されてい る (Philip, Ghorayeb, Leger, Menny, Bioulac, Dabadie, \& Guilleminault, 1997).一方，自己覚醒 条件では，仮眠後，覚醒水準が一定に保たれてお り，かつ，主観的眠気は低減していた。従って， 自己覚醒を用いた仮眠は，強制覚醒による仮眠以 上に有用であるといえる。

\section{引用文献}

American Sleep Disorders Association and Sleep Research Society 1992 EEG Arousals: Scoring rules and examples. Sleep, 15, 173-184.

Baddeley, A. D. 1968 A 3 min reasoning task on grammatical transformation. Psychonomic Science, 10, 341342.

Bell, C. R. 1980 Awakening from sleep at a pre-set time. Perceptual and Motor Skills, 50, 503-508.

Born, J., Hansen, K., Marshall, L., Malle, M., \& Fehm, H. 1999 Timing the end of nocturnal sleep. Nature, 397, 2930.

Broughton, R. J. 1989 Chronobiological aspects and models of sleep and napping. In D. F. Dinges \& R. J. Broughton (Eds.), Chronobiological, behavioral, and medical aspects of napping. New York: Raven Press. Pp. 71-98.

Broughton, R. J. 1998 SCN controlled circadian arousal and the afternoon "nap zoon". Sleep Research Online, 1, 166178.

Broughton, R. J., Aguirre, M., \& Dunham, W. 1988 A comparison of multiple and single sleep latency and cerebral evoked potential (P300) measures in the assessment of excessive daytime sleepiness in narcolepsy-cataplexy. Sleep, 11, 537-545.

Carskadon, M. A., Herman, K. B., \& Davis, S. S. 1990 Arousals in college students: can they beat the clock? Sleep Research, 19, 115.

Dinges, D. F. 1989 Napping patterns and effects in human 
adults. In D. F. Dinges \& R. J. Broughton (Eds.), Sleep and alertness, chronobiological, behavioral, and medical aspects of napping. New York: Raven Press. Pp. 171-204.

Dinges, D. F. 1992 Adult napping and its effects on ability to function. In C. Stampi (Ed.), Why we nap. Boston: Birkhäuster. Pp. 118-134

Hawkins, J. 1989 Sleep disturbance in intentional selfawakening: behavior-genetic and transient factor. Perceptual and Motor Skills, 69, 507-510.

Hawkins, J., \& Shaw, P. 1990 Sleep satisfaction and intentional self-awakening: an alternative protocol for selfreport data. Perceptual and Motor Skills, 70, 447-450.

Hayashi, M., Ito, S., \& Hori, T. 1999a The effects of a $20-$ min nap at noon on sleepiness, performance and EEG activity. International Journal of Psychophysiology, 32, 173180.

Hayashi. M., Watanabe, M., \& Hori, T. 1999b The effects of a 20 min nap in the mid-afternoon on mood, performance and EEG activity. Clinical Neurophysiology, 110, 272-279.

Karacan, I., Williams, R. L., Finley, W. W., \& Hursch, C. J. 1970 The effects of naps on nocturnal sleep: Influence in the need for stage-1, REM, and stage 4 sleep. Biological Psychiatry, 2, 391-399.

Lavie, P., Oksenberg, A., \& Zomer, J. 1979 It's time, you must wake up now. Perceptual and Motor Skills, 13, 334339.

Lavie, P., Wollman, M., \& Pollack, I. 1986 Frequency of sleep related accidents and hour of day. Sleep Research, 15,275 .

Lumley, M., Roehrs, T., Zorick, F., Lamphere, J., \& Roth, T. 1986 The alerting effects of naps in sleep deprived subjects. Psychophysiology, 23, 403-408.

前田素子・有富良二・白川修一郎 1994 短時間の昼間 仮眠の効果一眠気スケール（KSS）と反応時間による 検討一 睡眠と環境, 1, 63-68.

Mitler, M. A., Carskadon, M. A., Czeisler, C. A., Dement, W. C., Dinges, D. F., \& Graeber, R. C. 1988 Catastrophes, sleep, and public policy: consensus report. Sleep, 11 , 100-109.

Moorcroft, W. H., Kayser, K. H., \& Griggs, A. J. 1997 Subjective and objective confirmation of the ability to selfawaken at a self-predetermined time without using external means. Sleep, 20, 40-45.

Monk, H. T. 1989 A visual analog scale technique to measure global vigor and affect. Psychiatry Research, 27, 8999.

Pack, I. P., Pack, A. M., Rodgman, E., Cucchiara, A., Dinges,
D. F., \& Schwab, C. 1995 Characteristics of crashes attributed to the driver having fallen asleep. Accident Analysis \& Prevention, 6, 769-775.

Philip, P., Ghorayeb, I., Leger, D., Menny, J. C., Bioulac, B., Dabadie, P., \& Guilleminault, C. 1997 Objective measurement of sleepiness in summer vacation long-distance drivers. Electroencephalography and Clinical Neurophysiology, 102, 383-389.

Ravden, D., \& Polich, J. 1999 On P300 measurement stability: habituation, intra-trial block variation, and ultradian rhythms. Biological Psychology, 51, 59-76.

Rechtschaffen, A., \& Kales, A. 1968 A manual of standardized terminology, techniques and scoring system for sleep stage of human subjects. Washington DC: National Institute of Health.

Ruijter, J., De Ruiter M. B., \& Snel J. 2000 The effects of caffeine on visual selective attention to color: an ERP study. Psychophysiology, 37, 427-439.

杉田義郎・川上章良・渡辺环也 - 谷口充孝 - 寺島喜代 治・漆葉成彦 1998 夜間の微小覚醒と眠気一上気道 抵抗症候群と周期性四肢運動障害について一 臨床 精神医学, 27, 149-157.

Stampi, C., Mullington, J., Rivers, M., Campos, J. P., \& Broughton, R. 1990 Ultrashort sleep schedules: sleep architecture and recuperative value of 80,50 and $20 \mathrm{~min}$ naps. In J. Horne (Ed.), Sleep '90, Pontenagel: Bochum. Pp. 71-74.

Takahashi, M., \& Arito, H. 1998 Sleep inertia and autonomic effects on post-nap P300 event-related potential. Industrial Health, 36, 347-353.

Takahashi, M., \& Arito, H. 2000 Maintenance of alertness and performance by a brief nap after lunch under prior sleep deficit. Sleep, 23, 813-819.

玉木宗久・城田愛・林光緒・堀忠雄 1999 高齢者にお ける30分間の昼寝の回復効果 老年精神医学雑誌, 10, 1309-1317.

Walsleben, J. A., Squires, N. K., \& Rothenberger, V. 1989 Auditory event-related potentials and brain dysfunction in sleep apnea. Electroencephalography and Clinical Neurophysiology, 74, 297-311.

渡辺博 1969 注意睡眠の神経機序に関する臨床的研究 精神神経学雑誌, 71, 631-652.

Zepelin, H. 1986 REM sleep and the timing of selfawakenings. Bulletin of the Psychonomic Society, 24, 254256.

Zung, W. W. K., \& Wilson, W. P. 1974 Time estimation during sleep. Biological Psychiatry, 3, 159-164. 